\title{
Aerobic and anaerobic mineralization of organic material in marine sediment microcosms
}

\author{
Lars Stenvang Hansen, Thomas Henry Blackburn* \\ Department of Ecology and Genetics, University of Aarhus, Ny Munkegade, DK-8000 Aarhus C., Denmark
}

\begin{abstract}
Fluxes of total $\mathrm{CO}_{2}, \mathrm{O}_{2}, \mathrm{NO}_{3}{ }^{-}+\mathrm{NO}_{2}{ }^{-}, \mathrm{NH}_{4}{ }^{+}, \mathrm{DON}$ (dissolved organic nitrogen) and $\mathrm{HS}^{-}$ were measured across the interface of a coastal bay sediment for $43 \mathrm{~d}$. The seawater overlying the defaunated sediment cores was changed continuously. Two treatments were employed: oxygenated overlying water (OX-cores) and anoxic water (AN-cores). Fluxes were measured before and after addition of an organic substrate, and loss of POM (particulate organic matter) was measured at the end of the experiment. Loss of POC (particulate organic carbon) from the sediment was the same under aerobic and anaerobic conditions. However, the highest efflux of $\mathrm{CO}_{2}$ was measured in the OX-cores, and the highest efflux of DOC occurred in the AN-cores before and after addition of fresh substrate. Similarly, loss of PON (particulate organic nitrogen) from the sediment was the same in the 2 treatments, but the highest fluxes of $\mathrm{NH}_{4}{ }^{+}$and DON were measured in the AN-cores. Our conclusion is that degradation of POM is the same under both aerobic and anaerobic conditions, but that mineralization of organic molecules is less effective under anaerobic conditions. Before substrate addition there was an influx of $\mathrm{NO}_{3}{ }^{-}$in both $\mathrm{OX}$ - and AN-cores, and the estimated nitrification rate in the OX-cores was 1 to $2 \mathrm{mmol} \mathrm{m} \mathrm{m}^{-2} \mathrm{~d}^{-1}$ The estimated denitrification rate contributed 3 to $6 \%$ to total carbon respiration. After addition of the substrate, fluxes of all constituents increased. The estimated denitrification rate constituted $<3 \%$ of total respiration. There was a large efflux of $\mathrm{HS}^{-}$in AN-cores. During the experimental period, the losses of original POC and PON were calculated to be 2.6 and $4.0 \%$, respectively. Relative to the initial values, the pore water constituents increased with incubation, and the integrated AN/OX ratios for $\mathrm{NH}_{4}{ }^{+}$, DON and total $\mathrm{CO}_{2}$ were 1.2, 1.5 and 1.6, respectively, after $43 \mathrm{~d}$.
\end{abstract}

\section{INTRODUCTION}

Aerobic oxidation of organic matter in marine sediments is generally accepted to be the most important form of respiration in most situations (Sørensen et al. 1979, Jørgensen \& Sørensen 1985, Jørgensen \& Revsbech 1989). Recent investigations, however, have questioned this assumption (e.g. Henrichs \& Reeburgh 1987, Kristensen \& Blackburn 1987, Mackin \& Swider 1989). Aerobic respiration takes place in the oxic surface layer and is followed by nitrate reduction and sulfate reduction. In coastal marine sediments, however, the oxic zone often is only a few millimeters thick (Revsbech et al. 1980), and anaerobic respiration becomes dominant. Furthermore, much of the oxygen uptake is used to reoxidate the products of anaerobic respiration $\left(\mathrm{H}_{2} \mathrm{~S}, \mathrm{NH}_{4}{ }^{+}, \mathrm{CH}_{4}\right)$ at the oxic/anoxic interface (Jørgensen 1983a, b). Hargrave \& Phillips (1981) proposed that this could account for $50 \%$ of overall

\footnotetext{
- Addressee for correspondence
}

oxygen uptake, but the proportion obviously depends on the system and can approach $100 \%$ (Blackburn et al. 1988).

Very little is known about the changes in rates of organic degradation that occur when sediment becomes anoxic. In this investigation, the relative significance of aerobic and anaerobic respiration processes is investigated, using perfused sediment microcosms.

\section{MATERIALS AND METHODS}

Study site and sampling. Undisturbed sediment cores were collected from a station in Aarhus Bight, Denmark. At this locality ('Stn 16'), various aspects of sediment nitrogen cycling (Jensen et al. 1988, 1990, Lomstein et al. 1990), sulfate reduction (L. Moeslund \& B. B. Jørgensen pers. comm.) and oxygen fluxes (H. Rasmussen \& B. B. Jørgensen pers. comm.) have recently been investigated. The cores were collected in 
early November 1989. Water depth, salinity and temperature were $15 \mathrm{~m}, 22 \%$ and $13{ }^{\circ} \mathrm{C}$, respectively.

From a 'Haps' bottom corer (Kanneworff \& Nicolaisen 1973), which takes undisturbed sediment samples of $12 \mathrm{~cm}$ i.d., intact subcores $(7 \mathrm{~cm}$ i.d.) were collected for core-flow incubations; smaller subcores $(2.5 \mathrm{~cm}$ i.d.) were taken for analyses of sediment and pore water constituents. In addition, $75 \mathrm{l}$ of surface water was collected for use in the core-flow incubation experiment (see below). All materials were brought to the laboratory and kept in darkness at $15^{\circ} \mathrm{C}$ for $30 \mathrm{~d}$, exposed to air.

Sediment sectioning and chemical analysis. Triplicate cores $(2.5 \mathrm{~cm}$ i.d.) were sliced into $0-1,1-2,2-4$, 4-6 and 6-8 cm depth sections, and pore water was extracted by centrifugation (15 min, $3000 \mathrm{rpm}$ ). Samples were analysed for $\mathrm{NH}_{4}{ }^{+}, \mathrm{NO}_{3}{ }^{-}+\mathrm{NO}_{2}{ }^{-}$(dissolved inorganic nitrogen, DIN) and dissolved organic nitrogen (DON). DIN, DON, KCl-extractable $\mathrm{NH}_{4}^{+}$and alkalinity were similarly analysed for the incubation cores at the end of the core-flow experiment. Exchangeable $\mathrm{NH}_{4}{ }^{+}$(exch. $-\mathrm{NH}_{4}{ }^{+}$) was defined as $\mathrm{KCl}$ extractable $\mathrm{NH}_{4}{ }^{+}$minus pore water $\mathrm{NH}_{4}{ }^{+}$.

Specific density and water content (weight loss after $24 \mathrm{~h}$ at $105^{\circ} \mathrm{C}$ ) were determined in duplicate for each depth interval. The organic content (LOI) was determined by burning dry sediment for $12 \mathrm{~h}$ at $500^{\circ} \mathrm{C}$. Dry sediment, after treatment with acid (1 $\mathrm{N} \mathrm{HCl)}$ to remove carbonate, was analysed on a Carlo Erba NA$1500 \mathrm{CHN}$-analyser for particulate organic nitrogen (PON) and particulate organic carbon (POC). Carbonate was measured on pre-burned $\left(500^{\circ} \mathrm{C}\right)$ sediment on the CHN-analyser. Water which was used in the coreflow incubation experiment was filtered through GF/C filters to remove organic particles.

The sediment was defaunated to prevent death and decay of animals during the experiment. Cores were sealed with rubber stoppers, resulting in anoxic conditions after $24 \mathrm{~h}$. The macrofauna migrated to the surface of the sediment, where they were easily removed. After $4 \mathrm{~d}$ of anoxia, oxic conditions were reintroduced. Anoxic conditions were presumed to have little effect on the aerobic bacterial populations. However, some aerobic bacteria and meiofauna may have been killed by this treatment, which might have increased the content of mineralizable organic matter.

Experimental set-up. The experimental core-flow system is shown in Fig. 1. A peristaltic pump drove aerated reservoir water over 4 cores at a flow rate of 0.96 to $1.20 \mathrm{l} \mathrm{d}^{-1}$ core $^{-1}$. Net fluxes were calculated from the flow rate, sediment area and concentration of constituents in the in- and outflowing water (e.g. Nishio et al. 1983). The experiment was run in the dark at $15^{\circ} \mathrm{C}$ for $43 \mathrm{~d}$. On Day 7,2 cores received anoxic water $\left(\mathrm{N}_{2}\right.$-bubbled; AN-cores) while the other 2 cores

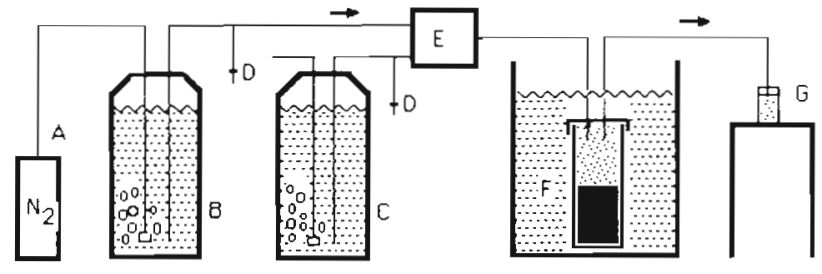

Fig. 1. Experimental flow system. (A) Nitrogen gas, (B) water reservoir, $\mathrm{N}_{2}$-bubbled, (C) water reservoir, atmospheric-bubbled, (D) drawing off initial water samples for measurement of inflowing concentrations, $(E)$ peristaltic water pump, $(F)$ incubation core with magnetic stirrer, (G) water samples for measurement of outflowing concentrations

continued to receive oxic water (OX-cores). The water overlying the cores was continuously mixed with a magnetic stirrer $(60 \mathrm{rpm})$. Control tests with $\mathrm{O}_{2}$ microelectrodes in the overlying water showed a homogeneous $\mathrm{O}_{2}$ concentration, which indicated that the mixing was effective.

Flux measurements. The water above the flow cores (260 to $280 \mathrm{ml}$ ) had a turnover time of ca $4 \mathrm{~h}$. Water samples from in-and outflowing water were analysed for DIN, DON, total $\mathrm{CO}_{2}\left(\mathrm{TCO}_{2}\right)$ and $\mathrm{O}_{2}$. Concentrations of $\mathrm{NH}_{4}{ }^{+}$and $\mathrm{NO}_{3}{ }^{-}$in the samples were determined by the standard autoanalyser methods of Solorzanó (1969) and Armstrong et al. (1967). DON was measured using a modified method described by Koroleff (1976). $\mathrm{TCO}_{2}$ was analysed potentiometrically by Gran-titration (Talling 1973), $\mathrm{O}_{2}$ concentration was measured by Winkler titration (Strickland \& Parsons 1972) and $\mathrm{HS}^{-}$was measured by the method of Cline (1969). Concentrations of $\mathrm{NO}_{3}{ }^{-}$and $\mathrm{NH}_{4}{ }^{+}$in the water reservoir were 4.5 and $2.5 \mu \mathrm{M}$ respectively. After $7 \mathrm{~d}$, the system had approached steady state (with respect to $\mathrm{O}_{2}$ and $\mathrm{CO}_{2}$ fluxes). On Day 20, a comminuted suspension of the macroalga Chondrus crispus was added to each core in an amount corresponding to 1.80 $\mathrm{mol} \mathrm{C} \mathrm{m} \mathrm{Col}^{-2}$ and $0.32 \mathrm{~mol} \mathrm{~N} \mathrm{~m}^{-2}$

\section{RESULTS}

\section{Visual observations}

Initially the sediment was light brown and oxidized in the upper 2 to $3 \mathrm{~cm}$. Below this zone the sediment was dark grey. In the AN-cores, the surface sediment turned darker. After the addition of substrate (Day 20), a discrete black band at the surface (1 to $6 \mathrm{~mm}$ ) was observed in all cores.

\section{Solid phase and pore water}

The initial porosity and LOI are shown in Table 1 The integrated loss of LOI for all cores during the 
Table 1. Initial (Day 0) values of sediment porosity, organic content (LOI), carbon and nitrogen content of LOI, and the C/N molar ratio. Standard deviations were in the range of 6 to $22 \%$

\begin{tabular}{|cccccr|}
\hline $\begin{array}{c}\text { Depth } \\
(\mathrm{cm})\end{array}$ & $\begin{array}{c}\text { Porosity } \\
\left(\mathrm{ml} \mathrm{cm}^{-3}\right)\end{array}$ & $\begin{array}{c}\text { LOI } \\
\text { (\% of dry weight) }\end{array}$ & $\begin{array}{c}\text { Organic C } \\
\text { (\% of dry weight) }\end{array}$ & $\begin{array}{c}\text { Organic N } \\
\text { (\% of dry weight) }\end{array}$ & $\begin{array}{c}\text { C/N } \\
\text { molar ratio }\end{array}$ \\
\hline $0-1$ & 0.79 & 9.7 & 2.86 & 0.33 & 9.57 \\
$1-2$ & 0.78 & 9.2 & 2.61 & 0.26 & 11.44 \\
$2-4$ & 0.77 & 8.2 & 2.76 & 0.25 & 11.23 \\
$4-6$ & 0.74 & 7.3 & 2.58 & 0.24 & 10.88 \\
$6-8$ & 0.70 & 6.9 & 2.69 & 0.22 & 12.45 \\
\hline
\end{tabular}

experimental period was 3 to $4 \%$. The initial values for POC and PON were 2.67 and $0.25 \%$ respectively (Table 1); of this, 2.6 and $4 \%\left(\sim 2.6\right.$ and $\left.0.31 \mathrm{~mol} \mathrm{~m}^{-2}\right)$ was lost during the $43 \mathrm{~d}$ incubation period. The loss, however, was not significantly different between OXand AN-core treatments.

At the end of the experiment, pore waters were anal-

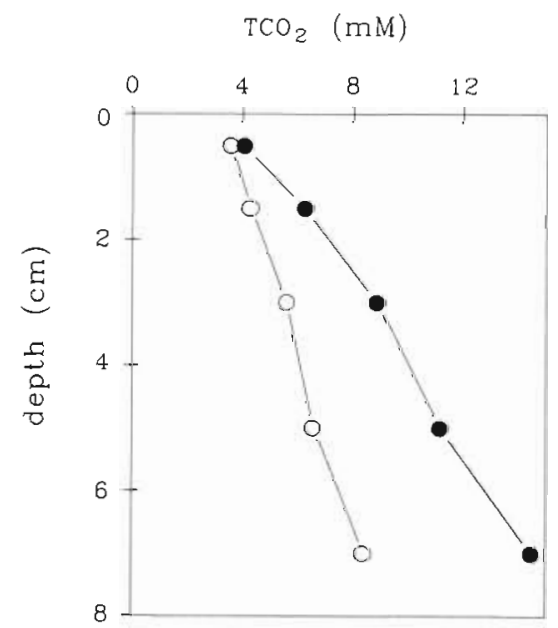

Fig. 2. Final porewater concentration of total $\mathrm{CO}_{2}\left(\mathrm{TCO}_{2}\right)$ plotted against depth for the 2 incubation types: (O) aerobic and $(\bullet$ ) anaerobic ( $\mathrm{SD}= \pm 0.3$ to 1.6 ) ysed for $\mathrm{TCO}_{2}, \mathrm{NO}_{3}{ }^{-}, \mathrm{NO}_{2}{ }^{-}, \mathrm{NH}_{4}{ }^{+}$and DON. Profiles of $\mathrm{TCO}_{2}$ are shown in Fig. 2. The integrated $\mathrm{AN} / \mathrm{OX} \mathrm{CO}_{2}$ ratio $\left(0\right.$ to $8 \mathrm{~cm}$ depth) was $1.6 . \mathrm{NO}_{3}{ }^{-}+\mathrm{NO}_{2}{ }^{-}$was detected only in the upper centimeter and at negligible concentrations $(<1 \mu \mathrm{M})$. Relative to the initial value, $\mathrm{NH}_{4}{ }^{+}$concentration in $\mathrm{OX}$ - and AN-cores increased by a factor of 1.5 and 2.0 respectively (Fig. $3 \mathrm{~A}$ ). A considerable difference was seen in exch.- $\mathrm{NH}_{4}{ }^{+}$between OX- and AN-cores (Fig. 3A). The integrated AN/OX exch. $-\mathrm{NH}_{4}{ }^{+}$ratio $(0$ to $8 \mathrm{~cm}$ depth) was 2.0. DON profiles are shown in Fig. 3B; the difference between $\mathrm{OX}$ - and $\mathrm{AN}$-cores was significant (AN/OX = 1.5). The ratios of initial/final DON concentrations were 1.1 and 0.7 for OX-and AN-cores, respectively. DON constituted a variable part (56 to $73 \%$ ) of dissolved nitrogen in the pore water

\section{Initial fluxes (Days 0 to 20)}

Oxygen consumption stabilized between Days 7 and 20 , at $63 \pm 1.7 \mathrm{mmol} \mathrm{m}^{-2} \mathrm{~d}^{-1}$ in the 4 cores (Fig. $4 \mathrm{~A}$ ). $\mathrm{TCO}_{2}$ flux across the sediment-water interface was similar on Day 7 (52 $\pm 2.7 \mathrm{mmol} \mathrm{m} \mathrm{m}^{-2} \mathrm{~d}^{-1}$ ) (Fig. 4B). After the AN-core incubation was initiated, $\mathrm{TCO}_{2}$ efflux gradually declined and remained at $55 \%$ of the
Fig. 3. (A) Concentrations of $(-)$ pore water $\mathrm{NH}_{4}{ }^{+}$and $(----)$exchangeable $\mathrm{NH}_{4}{ }^{+}$in $(0)$ aerobic and $(\bullet)$ anaerobic cores. ( $\square \cdot \cdot \cdot \square)$ Represents the initial concentrations ( $\mathrm{SD}=$ \pm 15 to 35$)$. (B) Concentrations of pore water dissolved organic nitrogen (DON); symbols as in (A)

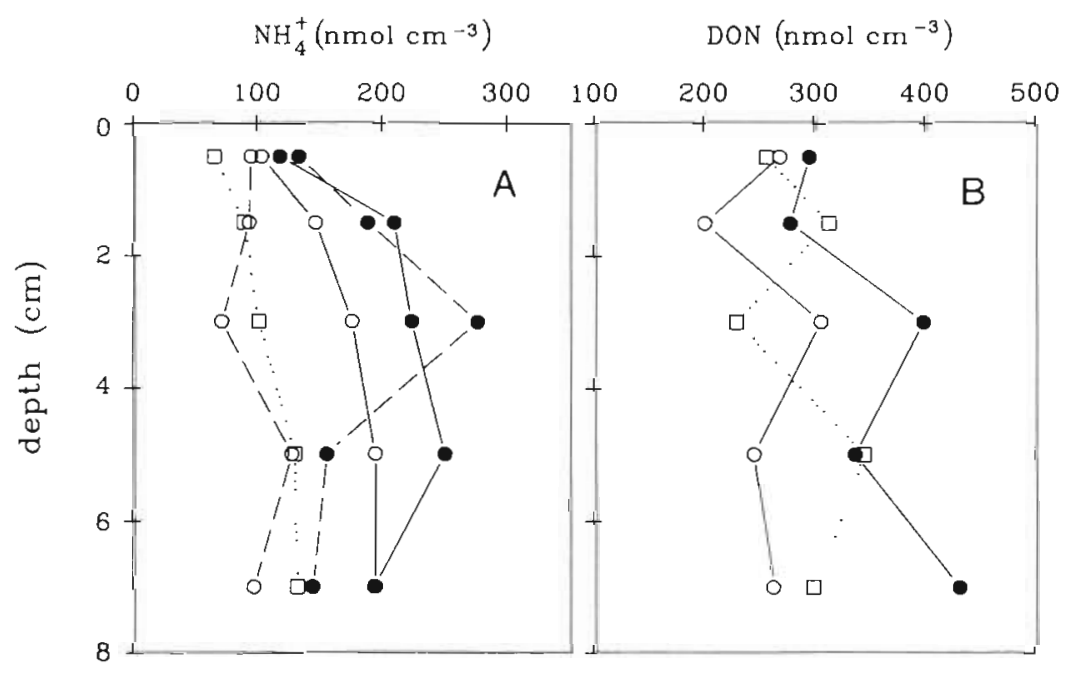


initial efflux. Low $\mathrm{HS}^{-}$efflux was detected in the ANcores (Fig. 4C). For $\mathrm{NH}_{4}{ }^{+}$, an influx of $0.76 \pm 0.05 \mathrm{mmol}$ $\mathrm{m}^{-2} \mathrm{~d}^{-1}$ was measured from Days 0 to 7 (Fig. 5A). After the onset of the AN-core incubation, a shift toward efflux of $\mathrm{NH}_{4}{ }^{+}$was observed (Days 8 to 20). After an initial efflux, a $\mathrm{NO}_{3}{ }^{-}$influx of ca $1.0 \pm 0.18 \mathrm{mmol} \mathrm{m}^{-2}$ $\mathrm{d}^{-1}$ in both OX-and AN-cores occurred (Fig. 5B). DON flux was unstable (Fig. 5C). The initial efflux increased significantly after the $\mathrm{AN}$-core incubation was initiated. Mean efflux rates were $0.85 \pm 0.70$ and $2.2 \pm$ $1.50 \mathrm{mmol} \mathrm{m} \mathrm{m}^{-2} \mathrm{~d}^{-1}$ in OX-and AN-cores, respectively.
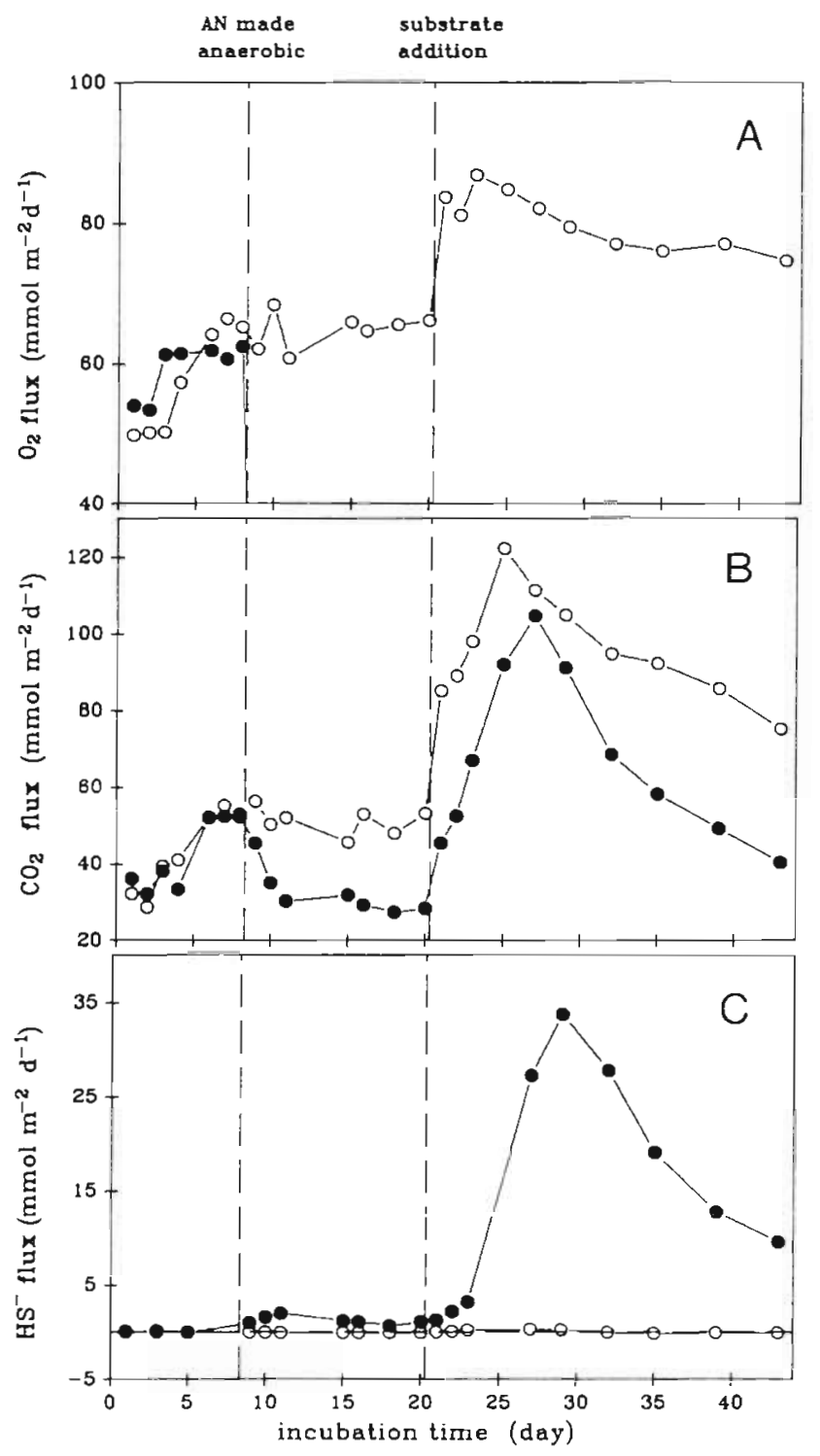

Fig. 4. $\mathrm{O}_{2}, \mathrm{TCO}_{2}$ and $\mathrm{HS}^{-}$fluxes over time, in 2 treatments: (c) aerobic, (-) anaerobic. On Day 7, AN-incubation was initiated, and organic substrate was added on Day 20. (A) $\mathrm{O}_{2}$ uptake by sediment ( $\mathrm{SD}= \pm 6.4$ to 12.3). (B) Efflux of total $\mathrm{CO}_{2}$ in the 2 core types ( $\mathrm{SD} \pm 5.1$ to 16.8). (C) Efflux of $\mathrm{HS}^{-}$ $\mathrm{HS}^{-}$here is converted to $\mathrm{O}_{2}$ equivalents $\left(2 \mathrm{O}_{2}\right.$ molecules are needed to oxidize $1 \mathrm{HS}^{-}$molecule) ( $\mathrm{SD}= \pm 0$ to 4.8 )

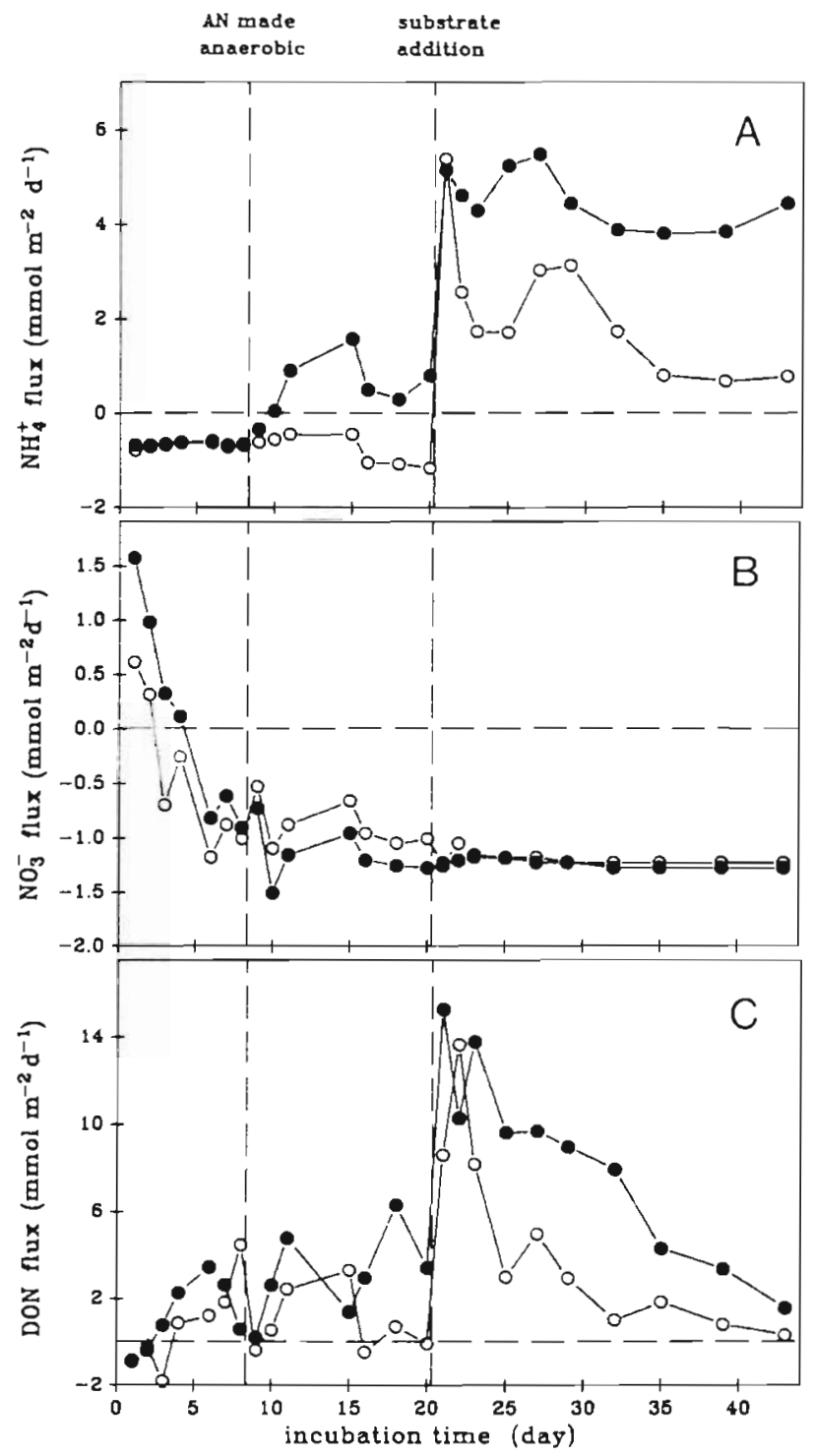

Fig. 5. $\mathrm{NH}_{4}{ }^{+}, \mathrm{NO}_{3}{ }^{-}$and DON fluxes over time, in 2 treatments: (') aerobic, ( $\bullet$ anaerobic. On Day 7. AN-incubation was initiated, and organic substrate was added on Day 20. $\mathrm{SD}=(\mathrm{A}) \pm 0.2$ to $1.1,(\mathrm{~B}) \pm 0$ to $0.4,(\mathrm{C}) \pm 0.6$ to 3.8

Fluxes after substrate addition (Days 21 to 43 )

Fluxes of $\mathrm{O}_{2}$ and $\mathrm{TCO}_{2}$ increased immediately after the addition of organic matter The fluxes reached a maximum of $86 \pm 12,122 \pm 14$ and $104 \pm 12 \mathrm{mmol}$ $\mathrm{m}^{-2} \mathrm{~d}^{-1}$ for $\mathrm{O}_{2}, \mathrm{CO}_{2}(\mathrm{OX})$ and $\mathrm{CO}_{2}(\mathrm{AN})$, respectively. These rates were 1.3-, 2.4- and 3.2-fold greater than the rates before substrate addition. The fluxes gradually declined and at the end of experiment finally reached levels 1.2-, 1.6- and 1.8-fold greater than the original steady-state values (Days 8 to 20) (Fig. 4A, B). After a few days' lag period, $\mathrm{HS}^{-}$efflux increased dramatically (Fig. 4 C); the flux reached a maximum of $34 \pm 11 \mathrm{mmol}$ 
$\mathrm{m}^{-2} \mathrm{~d}^{-1}$, then decreased gradually. Another consequence of the addition of organic matter was that net flux of $\mathrm{NH}_{4}{ }^{+}$increased and reached $5 \mathrm{mmol} \mathrm{m} \mathrm{m}^{-2} \mathrm{~d}^{-1}$. $\mathrm{NH}_{4}{ }^{+}$flux from the OX-cores declined to the original level, whereas AN-core flux stabilized at a high level (Fig. 5A) $\mathrm{NO}_{3}{ }^{-}$flux reached a level where almost all $\mathrm{NO}_{3}{ }^{-}$from the water was consumed by the sediment (Fig. 5B). The substrate addition resulted in a large pulse of DON release into the overlying water (max. rate $13.6 \pm 4.8$ and $15.3 \pm 4.0$ in OX and $\mathrm{AN}$; Fig. 5C). Subsequently, DON fluxes gradually declined.

The integrated fluxes of $\mathrm{TCO}_{2}$ during the $43 \mathrm{~d}$ experimental period were 2.2 and $1.4 \mathrm{~mol} \mathrm{~m}^{-2}$ in $\mathrm{OX}$ - and ANcores, respectively. This corresponded to 83 and $54 \%$ of the POC lost from the sediment. The integrated $\mathrm{N}$ fluxes $\left(\mathrm{NH}_{4}{ }^{+}+\mathrm{DON}\right)$ from sediment were 91 and $163 \mathrm{mmol} \mathrm{m}^{-2}$ in OX-and AN-cores, respectively, and corresponded to only 29 and $52 \%$ of the PON loss.

\section{DISCUSSION}

The overall loss of POC and PON from the 2 replicate cores was identical. Thus, the difference in observed carbon and nitrogen flux could be due to fermentation products lost as DOM and to denitrification products ( $\mathrm{N}$ gases). The integrated flux estimates were made from fluxes before organic-matter addition. $N$ flux values are given here with some reservations, however, due to the large variations in DON fluxes. The remaining $\mathrm{N}$ loss in OX-cores could be explained by a coupled nitrificationdenitrification rate of $5.1 \mathrm{mmol} \mathrm{m}^{-2} \mathrm{~d}^{-1}$. In comparison, Jensen et al. (1988) found at the same locality that the in situ denitrification rate did not exceed $1 \mathrm{mmol} \mathrm{m}{ }^{-2} \mathrm{~d}^{-1}$, measured over a year. However, S. Seitzinger (pers. comm.) has shown by another procedure that the acetylene method used by Jensen et al. (1988) might considerably underestimate the rate. Moreover, Blackburn \& Henriksen (1983) and Seitzinger et al. (1984) showed that 7 and $35 \%$, respectively, of $\mathrm{NH}_{4}{ }^{+}$production is nitrified and subsequently denitrified in similar coastal sediments. Thus, the calculated denitrification rate may be an overestimate. The mean $\mathrm{C} / \mathrm{N}$ molar ratio of detritus which disappeared from the sediment was 8.5 . The DON efflux also represents a transport of carbon, and the molar ratio 8.5 used in the measured DON fluxes gives an integrated quantity of organic carbon (DOC efflux) that equals the difference between POC lost from the sediment and the measured $\mathrm{TCO}_{2}$ flux.

\section{Pore water chemistry}

At the end of the experiment, sediment concentrations of dissolved and exch.- $\mathrm{NH}_{4}{ }^{+}$were significantly higher in AN- than in OX-cores (Fig. 3A). Part of this difference may be explained by a cessation of nitrification in AN-cores $\left(\mathrm{O}_{2}\right.$-free), which also may be partly responsible for the increased $\mathrm{NH}_{4}{ }^{+}$efflux on Days 7 to 20. DON concentration in AN-cores was significantly higher than in OX-cores. In contrast, Enoksson (1987) found a decreased DON concentration in anoxic incubations and explained this as a result of low proteolytic activity. In other experiments, we have also observed increased DON concentrations under anoxic conditions (Hansen \& Blackburn unpubl.). This increase might be due to products from increased fermentation in the absence of $\mathrm{O}_{2}$, or from a more effective aerobic degradation of DON in the OX-cores. The DON fraction constituted 56 to $73 \%$ of total dissolved nitrogen, compared to $86 \%$ found by Enoksson (1987). $\mathrm{TCO}_{2}$ concentrations were significantly higher in the AN-cores compared to OX-cores (Fig. 2). This observation does not agree well with the total $\mathrm{CO}_{2}$ flux in the AN-cores. There is no obvious explanation for those data. It seems improbable that an autotrophic process could capture a large proportion of the $\mathrm{CO}_{2}$ in the OX-cores.

\section{Flux measurements (Days 0 to 20)}

The initial steady-state rate of $\mathrm{O}_{2}$ consumption was $63 \mathrm{mmol} \mathrm{m} \mathrm{m}^{-2} \mathrm{~d}^{-1}$ (Fig. 4A). No $\mathrm{O}_{2}$ was detected in the $\mathrm{AN}$-core incubations. A respiratory quotient $\left(\mathrm{RQ}=\mathrm{CO}_{2}\right.$ efflux $/ \mathrm{O}_{2}$ influx) of 1 indicates that oxygen consumption is equivalent to $100 \%$ of the carbon lost from the sediment. In fact, we found $R Q$ ratios between 0.6 and 0.9 . The low $R Q$ values $(<1)$ are very different from those between 1 and 5 found by, e.g., Andersen \& Hargrave (1984) in other marine sediments. Three explanations are suggested: (1) $\mathrm{CO}_{2}$ was immobilised by carbonate precipitation; (2) chemoautotrophic $\mathrm{CO}_{2}$ fixation had occurred; (3) oxygen had chemically oxidized some inorganic reductants (e.g. $\mathrm{Mn}^{++}, \mathrm{Fe}^{++}$, HS $^{-}$). We found, however, no change in sediment carbonates; thus, no good explanation was found for the low RQ. Jørgensen (1983b) observed that most sulfide is eventually reoxidised by oxygen, and according to Hargrave \& Phillips (1981) about $50 \%$ of the oxygen consumption is used for this reoxidation. In fact, a RQ $>1$ was expected because of the FeS precipitation in the upper centimeter of the sediment. After the ANcore incubation was begun, a $45 \%$ decrease in $\mathrm{TCO}_{2}$ production $\left(\mathrm{TCO}_{2}\right.$ flux) was observed (Fig. 4B). Therefore, with some reservations, anaerobic respiration is estimated to account for $55 \%$ of the overall respiration. Jørgensen \& Sørensen (1985) found the partitioning between aerobic and anaerobic respiration to be 65 and $35 \%$, respectively, in an estuarine sediment. In contrast, later experiments showed a partitioning of 
3 to $14 \%$ and 65 to $85 \%$, respectively (Mackin \& Swider 1989). These authors concluded that aerobic respiration was quantitatively important only when the overall decomposition of organic matter was low, or when intensive bioturbation had occurred. In fact, almost any proportion of carbon oxidation by $\mathrm{O}_{2}$ may be found, depending on the amount of carbon added to the sediment (Blackburn 1991).

Sulfate reduction is assumed to account for $90 \%$ of total anaerobic respiration (Jørgensen 1983b), and the corresponding $\mathrm{HS}^{-}$efflux would theoretically be about $25 \mathrm{mmol} \mathrm{m} \mathrm{m}^{-2} \mathrm{~d}^{-1}$ (in $\mathrm{O}_{2}$ equivalents) in the present experiment. Due to the coloration of the surface sediment (light brown, indicating presence of ferric oxyhydroxides), the reason for the low HS efflux is assumed to be FeS precipitation. The reaction between reactive iron and sulfide is rapid, and the concentration of reactive $\mathrm{Fe}$ is high at the present locality $(>2.4 \mathrm{~mol}$ $\mathrm{m}^{-2}$; B. Thamdrup pers. comm.)

The occurrence of an initial net flux of $\mathrm{NH}_{4}{ }^{+}$from water to sediment indicates that the $\mathrm{NH}_{4}{ }^{+}$flux to the sediment surface from the lower sediment strata was insufficient to meet the demand for $\mathrm{NH}_{4}{ }^{+}$in synthetic and nitrification processes. After the start of the ANcore incubation, the $\mathrm{NH}_{4}{ }^{+}$influx changed direction, possibly due to absence of nitrification. Nitrification in OX-cores was estimated to be 1 to $2 \mathrm{mmol} \mathrm{m} \mathrm{m}^{-2} \mathrm{~d}^{-1}$. based on the difference in $\mathrm{NH}_{4}{ }^{+}$flux between $\mathrm{OX}$ - and AN-cores and assuming an equal ratio of mineralization. Thus the net $\mathrm{NH}_{4}{ }^{+}$production rate was the $\mathrm{NH}_{4}{ }^{+}$ efflux in AN-cores, which varied between 0.4 and 1.8 mmol m${ }^{-2} \mathrm{~d}^{-1}$ (Days 15 to 20 ). The sum of net $\mathrm{NH}_{4}{ }^{+}$ production plus $\mathrm{NO}_{3}{ }^{-}$influx provides an estimated denitrification rate of 1.4 to $2.8 \mathrm{mmol} \mathrm{m} \mathrm{m}^{-2} \mathrm{~d}^{-1}$. However, the difference in $\mathrm{NH}_{4}{ }^{+}$fluxes between $\mathrm{OX}$ - and AN-cores could be due to differences in $\mathrm{N}$-incorporation efficiencies in aerobic and anaerobic bacteria. Denitrification would have been responsible for 3 to $6 \%$ of the total respiration, which aggrees with values from other in situ experiments (Sørensen et al. 1979, Jørgensen \& Sørensen 1985). As mentioned above, denitrification would have to occur at $5.1 \mathrm{mmol} \mathrm{m}^{-2} \mathrm{~d}^{-1}$ to account for the PON loss. It should be noted, how ever, that aerobic bacteria and meiofauna might have been killed under anaerobic conditions and thus have contributed to an increased net mineralization; this would lead to an overestimate of nitrification and denitrification rates. The effect would be eliminated when the system is at steady-state conditions. The simultaneous influx of $\mathrm{NH}_{4}{ }^{+}$and $\mathrm{NO}_{3}{ }^{-}$in $\mathrm{OX}$-cores indicates that the entire net $\mathrm{NH}_{4}{ }^{+}$production was nitrified, and that the coupled nitrification-denitrification was $100 \%$. Blackburn \& Henriksen (1983), Nishio et al. (1983) and Jørgensen \& Revsbech (1989) calculated for different marine sediments that 6 to $70 \%$ of the $\mathrm{NH}_{4}{ }^{+}$production was nitrified. In the present experiment, 16 to $55 \%$ of denitrification was coupled to nitrification in the sediment, the remaining $\mathrm{NO}_{3}{ }^{-}$being supplied from the overlying water.

When a steady-state $\mathrm{NO}_{3}{ }^{-}$flux was attained (Days 8 to 43 ), $90 \%$ of the $\mathrm{NO}_{3}{ }^{-}$present in the overlying water was consumed and used for respiration.

During the experiment, DON fluxes were highly variable, possibly due to analytic uncertainties. DON was the most important $N$ component lost from the sediment, and the mean $\mathrm{AN} / \mathrm{OX}$ flux ratio ( $\sim 3$ ) reflects the difference in the pore water concentrations (ratio $\approx$ 1.5). In contrast, Enoksson (1987) found a positive correlation between DON flux and $\mathrm{O}_{2}$ concentration.

\section{Flux measurements after substrate addition (Days 21 to 43 )}

At steady state, after supplying organic matter to the sediments, the changes in fluxes express the integrated reactions due to the added substrate. The $\mathrm{O}_{2}$ consumption rate was raised only $35 \%$ by the substrate addition. At this time the $\mathrm{O}_{2}$ concentration in the overlying water was reduced to $20 \mu \mathrm{M}$, and the potential $\mathrm{O}_{2}$ flux to the sediment was limited by diffusion through the benthic boundary layer (Hall et al. 1989, Gundersen \& Jørgensen 1990). Under these conditions (i.e. at $20 \mu \mathrm{M}$ $\mathrm{O}_{2}$ in overlying water), the ratio of aerobic:anaerobic respiration was 20:80. Theoretically, the entire oxygen consumption could have been used for $\mathrm{HS}^{-}$reoxidation (Jørgensen \& Revsbech 1989), and this may occur at the low $\mathrm{O}_{2}$ concentration.

The flux of $\mathrm{TCO}_{2}$ increased dramatically after substrate addition - 144 and $271 \%$ in $\mathrm{OX}$ - and AN-cores, respectively; this difference between $O X$ - and $A N$ cores remained almost constant. The increase in $\mathrm{TCO}_{2}$ efflux was relatively larger in AN-cores, which indicated a high potential activity by the anaerobic bacteria when suitable substrate was available. The large sulfide efflux (Fig. 4C) indicated a stimulation of sulfate-reducing bacteria. However, $\mathrm{HS}^{-}$efflux corresponded to only $30 \%$ of the anaerobic respiration; this must have been due to FeS precipitation. In situ similar precipitation has been observed after sedimentation of a spring phytoplankton bloom (Jensen et al. 1990, L. Moeslund \& B. B. Jorgensen pers. comm.). During this period, the $R Q$ was $>1$, which was due to increased anaerobic respiration coupled with low $\mathrm{O}_{2}$ concentration

All $\mathrm{NO}_{3}{ }^{-}$for denitrification came from the overlying water, and denitrification accounted for less than $3 \%$ of total respiration. Because of the aerobic heterotrophic competition for $\mathrm{O}_{2}$, nitrification might have been eliminated in the $\mathrm{OX}$-cores, and therefore the denitrification 
rate was possibly the same in AN-cores (Blackburn 1990, Jensen et al. 1990).

$\mathrm{NH}_{4}{ }^{+}$efflux showed an immediate large increase in response to the supply of fresh organic material (Fig. 5A). The efflux rate gradually declined and reached a steady state at the end of the experiment. The difference in $\mathrm{NH}_{4}{ }^{+}$efflux between $\mathrm{OX}$ - and AN-cores was larger than might be expected from nitrification in the OX-cores. The lowered redox potential $\left(\mathrm{E}_{\mathrm{h}}\right)$ in $\mathrm{AN}$ cores could be a reason for the relatively larger $\mathrm{NH}_{4}{ }^{+}$ efflux, due to dissolution of organic colloids or $\mathrm{Fe}^{3+}$ $\mathrm{NH}_{4}{ }^{+}$complexes at low $\mathrm{E}_{\mathrm{h}}$ (Balzer 1984). Furthermore, gross $\mathrm{NH}_{4}^{+}$mineralization could have been underestimated as a consequence of assimilation of $\mathrm{NH}_{4}{ }^{+}$into an increased bacterial biomass (Garber 1984).

Substrate addition resulted in a significant increase in DON efflux (Fig. 5C), as also shown by Enoksson (1987). An increase in sediment DON could have been due to a rate of production which was greater than the rate of DON degradation. Garber (1984) showed that $9 \%$ of an organic supply was immediately released by hydrolysis. The DON fluxes gradually declined towards the end of the experiment, when the substrate became more refractory. The ratio of DON flux for ANcores vs OX-cores was 2, again indicating that DON accumulation increased under anoxic conditions. Possibly DON was not mineralized so rapidly under anoxic conditions.

\section{Decomposition of added substrate}

As a consequence of changes effected by the fresh substrate, it is possible to estimate both the rate of decomposition and lability of the substrate. The quantity of added substrate corresponded to $1.8 \mathrm{~mol} \mathrm{C} \mathrm{m}^{-2}$ and $0.32 \mathrm{~mol} \mathrm{~N} \mathrm{~m}{ }^{-2}$. The integrated excess of $\mathrm{TCO}_{2}$ flux in OX-cores corresponded to $58 \%$ of the added substrate, and the increase in DOC (calculated from DON) represented $17 \%$ of the added substrate. The respective values for $\mathrm{TCO}_{2}$ and $\mathrm{DOC}$ in the $2 \mathrm{AN}$ cores were 46 and $30 \%$. With respect to nitrogen, 35 and $53 \%$ were lost from the substrate in OX-and ANcores, respectively (DON + DIN flux). The $\mathrm{C} / \mathrm{N}$ ratio in the mineralized substrate was surprisingly high (18.5 in OX and 11.4 in AN); this is not in agreement with earlier reports that $\mathrm{N}$-containing material is mineralized preferentially (e.g. Lancelot \& Billen 1985. Kristensen \& Blackburn 1987). In fact, there was a significant build-up of exch.- $\mathrm{NH}_{4}{ }^{+}$in the sediment; this discrepancy could have been due to bacterial assimilation of $\mathrm{NH}_{4}{ }^{+}$(Garber 1984). The DON fluxes corresponded to 49 and $57 \%$ of total N-flux in OXand AN-cores respectively. These rates suggest that the 'half-life' for organic carbon and nitrogen of the substrate is on the order of 2 and 3-4 wk respectively. These values agree with both in situ and experimental decomposition rates for algal detritus in other experiments (Graf et al. 1983, Garber 1984, Enoksson 1987).

Based on the carbon fluxes, it is calculated that the substrate contained a labile fraction $(33 \%)$ and a fraction with a lower decay constant $(30 \%)$, with the remaining being refractory. These ratios differ from the 50:25:25\% composition observed by Lancelot \& Billen (1985).

In the present experiment, mineralization of the algae $\left(\mathrm{CO}_{2}\right.$ flux $)$ was apparently the same under oxic and anoxic conditions. In contrast, Westrich \& Berner (1984) found increased decomposition in the presence of $\mathrm{O}_{2}$. The decomposition of DON was probably faster under oxic conditions in the present experiment. Foree \& MacCarty (1970) found decay rates of algae to be equal under oxic and anoxic conditions.

\section{CONCLUSION}

The most significant conclusion from this experiment is that mineralization of organic material (losses of POC and PON) was the same under anaerobic and aerobic conditions. The rate of anaerobic degradation has long been known (Aller 1980, Berner 1980, Santschi et al. 1990), but only recently has it been established that sulfate reduction is a very efficient process (Henrichs \& Reeburgh 1987, Canfield 1989, Mackin \& Swider 1989). The present results indicate, however, that there may be very significant differences between aerobic and anaerobic degradation of DOC. Under both conditions there was quite a high flux of DON (and by inference DOC) from the sediment before the addition of fresh substrate. Total carbon fluxes $\left(2.6 \mathrm{~mol} \mathrm{~m}{ }^{-2}\right)$ were equal in $\mathrm{OX}$ - and $\mathrm{AN}$ cores. Of this, DOC represented ca 17 and $46 \%$ respectively: there was a higher flux of DOC under anoxic conditions. Similarly, after the addition of substrate, total carbon fluxes were $1.35 \mathrm{~mol} \mathrm{~m}^{-2}$ from the OX-and AN-cores, of which DOC represented ca 23 and $39 \%$ respectively. Our tentative conclusion is that hydrolysis of POM may be the same with or without oxygen, but that mineralization of dissolved organic molecules may be less efficient under anoxic conditions. This is partially confirmed by the higher concentration of DON in the pore water of AN-cores at the end of the experiment.

There are few experimental data available from other investigations to confirm or contradict this hypothesis of similar rates of hydrolysis of particulate material and dissimilar rates of mineralization of dissolved molecules. However, in a similar type of exper- 
iment, $\mathrm{CO}_{2}$ production was found to be slightly higher under anoxic conditions (Kristensen \& Blackburn $1987)$.

\section{LITERATURE CITED}

Aller, R. C. (1980). Diagenetic processes near the sedimentwater interface of Long Island Sound. I. Decomposition and nutrient element geochemistry ( $S, N, P$ ). Adv. Geophys. 22: $237-415$

Anderson, F. O., Hargrave, B. T. (1984). Effect of Spartina detritus enrichment on aerobic/anaerobic benthic metabolism in an intertidal sediment. Mar. Ecol. Prog. Ser. 16: $161-171$

Armstrong, F. A. J., Stearns, C. R., Strickland, J. D. H. (1967). The measurements of upwelling and subsequent biological processes by means of the Technicon Autoanalyser and associated equipment. Deep Sea Res. 14: 381-389

Balzer, W. (1984). Organic matter degradation and biogenic element cycling in a near shore sediment (Kiel Bight). Limnol. Oceanogr. 29: 1231-1246

Berner, R. A. (1980). Early diagenesis: a theoretical approach Princeton University Press, Princeton

Blackburn, T H. (1990). Denitrification model for marine sediments. In: Sorensen, J., Revsbech, N. P. (eds.) Denitrification in soil and sediment. Plenum Press, New York, p. 323-337

Blackburn, T H. (1991). Accumulation and regeneration, processes at the benthic boundary layer. In: Mantoura, R. R. C., Martin, J. M., Wollast, R. (eds.) Ocean margin processes in global change. Wiley, Chichester, p. 181-195

Blackburn, T H., Henriksen, K. (1983). Nitrogen cycling in different types of sediments from Danish Waters. Limnol. Oceanogr. 28: 477-493

Blackburn, T H., Lund, B. Aa., Krom, M. D. (1988). C- and Nmineralization in the sediment of earthen marine fishponds. Mar. Ecol. Prog. Ser. 44: 221-227

Canfield, D. E. (1989). Sulfate reduction and oxic respiration in marine sediments: implications for organic carbon preservation in euxinic environments. Deep Sea Res. 36:121-138

Cline, J. D. (1969). Spectrophotometric determination of hydrogen sulfide in natural waters. Limnol. Oceanogr. 14: $454-458$

Enoksson, V (1987). Nitrogen flux between sediment and water and its regulatory factors in coastal areas. Ph.D. dissertation, University of Göteborg, Sweden

Foree, E. G. McCarty, P. L. (1970). Anaerobic decomposition of algae. Environ. Sci. Technol. 10: 842-949

Garber, J. H. (1984). ${ }^{15} \mathrm{~N}$ tracer study of the short term fate of particulate organic nitrogen at the surface coastal marine sediments. Mar Ecol. Prog. Ser 16: 89-104

Grat, G., Schulz, R., Peinert, R., Meyer-Reil, L. A. (1983). Benthic response to sedimentation event during autumn to spring at a shallow-water station in the western Kiel Bight. Mar Biol. 77: 235-246

Gundersen, J. K., Jørgensen, B. B. (1990). Microstructure of diffusive boundary layers and the oxygen uptake of the sea floor. Nature, Lond. 345: 604-607

Hall, P. O. J., Anderson, L. G., Rutgers van der Loeff, M. M., Sundby, B., Westerlund, S. F. G. (1989). Oxygen uptake kinetics in the benthic boundary layer Limnol. Oceanogr. 34: $734-746$

Hargrave, B. T., Phillips, G. A. (1981). Annual in situ carbon dioxide and oxygen flux across a subtidal sediment. Estuar. coast. Shelf Sci. 12: 725-737
Henrichs, S. M., Reeburgh, W. S. (1987). Anaerobic mineralization of marine sediment organic matter: rates and the role of anaerobic processes in the oceanic carbon economy. J. Geomicrobiol. 5: 191-236

Jensen, M. H. Andersen, T. K., Sørensen, J. (1988). Denitrification in coastal bay sediment: regional and seasonal variation in Aarhus Bight, Denmark. Mar Ecol. Prog. Ser. 48: $155-162$

Jensen, M. H., Lomstein, E., Sørensen, J. (1990). Benthic $\mathrm{NH}_{4}{ }^{+}$ and $\mathrm{NO}_{3}{ }^{-}$flux following sedimentation of a spring phytoplankton bloom in Aarhus Bight, Denmark. Mar Ecol. Prog. Ser. 61. 87-96

Jørgensen, B. B. (1983a). The microbial sulfur cycle. In: Krumbein. W. E. (ed.) Microbial geochemistry. Blackwell, Oxford, p. 91-124

Jørgensen, B. B. (1983b). Processes at the sediment-water interface. In: Bolin, B., Cook, R. B. (eds.) The major biochemical cycles and their interactions. Wiley, Chichester, p. 477-509

Jørgensen, B. B., Revsbech, N. P. (1989). Oxygen uptake, bacterial destribution, and carbon-nitrogen-sulfur cycling in sediments from the Baltic Sea-North Sea transition. Ophelia 31: 29-49

Jørgensen, B. B., Sørensen, J. (1985). Seasonal cycles of $O_{2}$ $\mathrm{NO}_{3}{ }^{-}$and $\mathrm{SO}_{4}^{-}$reduction in estuarine sediments: the significance of an $\mathrm{NO}_{3}{ }^{-}$reduction maximum in spring. Mar. Ecol. Prog. Ser. 24: 65-74

Kanneworff, E., Nicolaisen, W (1973). The 'Haps'; a frame supported bottom corer. Ophelia 10: 119-128

Koroleff, F. (1976). Total and organic nitrogen. In: Grasshoff K. (ed.) Methods of seawater analysis. Verlag Chemie, New York, p. 167-181

Kristensen, E., Blackburn, T H. (1987). The fate of organic carbon and nitrogen in experimental marine sediment system: influence of bioturbation and anoxia. J. mar. Res. 45: 231-257

Lancelot, C., Billen, C. (1985). Carbon-nitrogen relationship in nutrient metabolism of coastal marine ecosystem. Adv. aquat. Microbiol. 3: 263-321

Lomstein, E., Jensen, M. H., Sørensen, J. (1990). Intracellular $\mathrm{NH}_{4}{ }^{+}$and $\mathrm{NO}_{3}{ }^{-}$pools associated with deposited phytoplankton in a marine sediment (Aarhus Bight, Denmark). Mar. Ecol. Prog. Ser. 61 97-105

Mackin, J. E., Swider, K. T. (1989). Organic matter decomposition pathway and oxygen consumption in coastal marine sediments. J. mar. Res. 47: 681-716

Nishio, I., Koike, I., Hattori, A. (1983). Estimates of denitrification and nitrification in coastal and estuarine sediment Appl, environ. Microbiol. 45: 444-450

Revsberch, N. P., Sorensen, J., Blackburn, T H., Lomholt, J. P. (1980). Distribution of oxygen in marine sediments measured with microelectrodes. Limnol. Oceanogr. 25: 403-411

Santschi, P., Hohener, P., Benoit, G., Buchholtztenbrink, M. (1990). Chemical processes at the sediment water interface. Mar Chem. 30: 269-316

Seitzinger, S. P., Nixon, S. W., Pilson, M. E. Q. (1984). Denitrification and nitrous oxide production in a coastal marine sediment ecosystem. Limnol. Oceanogr. 29: 73-83

Solorzanó, L. (1969). Determination of ammonia in natural waters by the phenyl-hypoclorite method. Limnol. Oceanogr 14: 799-801

Sørensen, J., Jørgensen, B. B., Revsbech, N. P. (1979). A comparison of oxygen, nitrate and sulfate respiration in coastal marine sediments. Microb. Ecol. 5: 105-115

Strickland, J. D., Parsons, T R. (1972). A practical handbook of seawater analysis, 2nd edn. Bull. Fish. Res. Bd Can. 167: $1-310$ 
Talling, J. F. (1973). The application of some electrochemical methods to the measurements of photosynthesis and respirations in fresh waters. Freshwat. Biol. 3: 335-363

This article was submitted to the editor
Westrich, J. T., Berner, R. A. (1984). The role of sedimentary organic matter in bacterial sulfate reduction: the $\mathrm{G}$ model tested. Limnol. Oceanogr. 29: 236-249

Manuscript first received: January 14, 1991

Revised version accepted: June 17, 1991 